\title{
INVENTARISASI MAKANAN TRADISIONAL JAWA UNSUR SESAJI DI PASAR-PASAR TRADISIONAL KABUPATEN BANTUL
}

\author{
Endang Nurhayati, Mulyana, Venny Indria Ekowati, Avi Meilawati \\ FBS Universitas Negeri Yogyakarta \\ email: endang_fbs@yahoo.com
}

\begin{abstract}
Abstrak: Inventarisasi Makanan Tradisional Jawa Unsur Sesaji di PasarPasar Tradisional Kabupaten Bantul. Tujuan penelitian ini adalah: (1) menginventarisasi makanan tradisional Jawa jenis jajan pasar di pasar-pasar tradisional Kabupaten Bantul; (2) mendeskripsikan namamakanan tradisional Jawa unsur sesaji di berbagai ritual Jawa. Jenis penelitian ini adalah penelitian survey, yang menggunakan pendekatan teori etnolinguistik. Penelitian dilakukan di 27 pasar tradisional Kabupaten Bantul. Hasil penelitian menunjukan ada 45 jenis jajan pasar yang masih dijual di pasar tradisional Kabupaten Bantul. Makanan terbuat dari bahan baku singkong, beras, jagung, dan gandum. Cara pengolahan makanan ada yang digoreng, dikukus, direbus dan dibakar. Selain makanan tersebut ditemukan pula jenis makanan umbi-umbian, dan kacangkacangan. Dari 45 jenis jajan pasar tersebut tidak seluruhnya masuk unsur sesaji Jawa. Nama makanan yang termasuk sesaji antara lain: ketan, kolak, apem, aneka jenang, peyek, kacang-kacangan, umbi-umbian rebus atau lazim disebut pala kependhem, jadah, wajik, dan lemper.
\end{abstract}

Kata kunci: inventarisasi, makanan tradisional Jawa, unsur sesaji

\begin{abstract}
Inventories Javanessee Traditional Offering Food in Bantul Traditional Market. This research aims to (1) inventories Javanessee traditional food in Bantul traditional market, (2) describes the name of traditional food as offerings which is related with Javanesee philosophy in Javanessee tradition. It employed the survey technique, it used ethnolinguistic approach. The data sources were collected from 27 traditional markets in Bantul. There were 45 kinds of jajan pasar in traditional market in Bantul region. The food were made from cassava, rice, corn, and flour. The coocking techniques were fried, boiled, steam and roasted. There were food made from peanut and tuber. The food used for offerings were ketan, kolak, apem, jenang, peyek, kacang-kacangan, pala kependhem, jadah, wajik and lemper.
\end{abstract}

Keywords: inventory, javanessee traditional food, offerings

\section{PENDAHULUAN}

Berbagai jenis makanan dapat dipakai sebagai salah satu ukuran tinggi rendahnya kebudayaan dari suatu bangsa. Makanan tradisional merupakan wujud budaya yang berciri kedaerahan, spesifik, beraneka macam, dan jenisnya mencerminkan potensi alam daerah masing-masing. Makanan tidak hanya sebagai sarana pemenuhan kebutuhan gizi seseorang, tetapi juga berguna untuk mempertahankan hubungan antarmanusia, manusia dengan Tuhan, dan dapat pula dipromosikan untuk menunjang pariwisata yang selanjutnya dapat dijadikan sumber pendapatan daerah. 
Masyarakat Indonesia, salah satunya masyarakat Jawa sejak dahulu kala sudah memiliki makanan tradisional yang mantap, baik makanan utama, jajan pasar,ataupun minuman tradisionalnya. Kondisi yang seperti itu menyebabkan masyarakat Indonesia lebih memilih mengkonsumsi makanan tradisional yang lezat, sehat, aman, dan sesuai dengan keyakinan, moral, dan budaya mereka (Susanto dalam Rosyidi, 2011).

Menurut penelitian Retnaningsih dan Pratiwi, jenis makanan tradisional Jawa di Kota Yogyakarta ada 73 jenis yang terbuat dari bahan baku non umbi. Rata-rata kandungan gizi (energi, protein dan lemak) dari makanan tradisional non umbi per ukuran penyajian tersebut yaitu: energi (34,39 s/d. 215,84 kkal), protein $(0,8 \mathrm{~s} / \mathrm{d} .15 .59 \mathrm{~g})$ dan lemak $(0,6$ s/d. 16,67 g). Jenis makanan tradisional berikutnya terbuat dari bahan baku umbi-umbian sebanyak 44 jenis, dengan rata-rata kandungan gizi (energi, protein dan lemak) per ukuran penyajian adalah sebagai berikut: energi (88 s/d. 502 kkal), protein $(0,60 \mathrm{~s} / \mathrm{d} .5 .60 \mathrm{~g})$ dan lemak (0,30 s/d. 28,10 g) (Retnaningsih dan Pratiwi, 2004). Kandungan gizi yang sangat bervariasi dari makanan tradisional itu disebabkan oleh variasi jenis makanan beserta komposisi bahan lainnya.

Penelitian di atas, dilakukan di Kota Yogyakarta. Untuk melengkapi peta makanan tradisional Jawa di DIY perlu dilakukan penelitian sejenis di kabupaten-kabupaten. Salah satu kabupaten yang memiliki aneka ragam makanan tradisional adalah Kabupaten Bantul. Berdasarkan kajian pustaka di Kabupaten Bantul belum pernah dilakukan penelitian mengenai jenis makanan tradisional. Padahal Kabupaten Bantul merupakan salah satu kabupaten yang memiliki keragaman budaya. Hal tersebut ditandai oleh adanya situs-situs budaya, dan pemertahanan adat yang diyakininya.

Upacara adat yang masih berlaku DI Kabupaten Bantul antara lain nyadran, majemukan, bersih desa, dan upacara daur hidup. Upacara nyadran yang terkenal adalah nyadran Makam Sewu yaitu ritual mendoakan dan ngalab berkah kepada Panembahan Bodho yang dimakamkan di makam tersebut. Ritual bersih desa atau majemukan masih diselenggarakan di hampir setiap kecamatan, lazimnya setelah panen raya. Penyelenggaraan upacara tersebut selalu menghadirkan makanan untuk peserta ritual dan makanan khas untuk sesaji ritual. Makanan untuk sesaji selalu berciri kedaerahan, atau produk setempat. Hal ini disebabkan oleh keyakinan dan harapan yang disimbolkan pada jenis makanan yang disajikan. Setiap makanan memiliki makna, yang konsepnya berupa harapan dan keinginan para pelaku upacara terhadap Tuhannya.

Disamping upacara adat yang bersifat masal atau sosial seperti di atas, ritual Jawa yang bersifat pribadi masih juga diselenggarakan. Upacara adat yang dimaksud antara lain tingkeban atau upacara kehamilan tujuh bulan, mantu atau pernikahan, selapanan, khitan, dan nyewu pada upacara selamatan kematian, dan lain-lainnya. Dalam upacara ini makanan tradisional akan hadir untuk ubarampe sajen, kenduri dan suguhan para tamu atau orang-orang yang terlibat dalam ritual tersebut.

Berdasarkan fakta sejarah, Indonesia mempunyai ragam budaya, adat, tradisi dan kehidupan yang khas dan otonom, termasuk penyediaan bahan pangan. Sebagai Negara berbasis pertanian dan kelautan Indonesia pantas menjadi negara swasembada pangan. Dengan kondisi tersebut tidak mengeherankan 
jika ketahanan pangannya kuat. Pangan tradisional yang berbasis sumber alam, dan hayati, menjadi penopang utama ketahanan pangan dan ketahanan industri makanan lokal, yang sangat dibutuhkan untuk mencukupi kehidupan sehari-hari dan ritual masyarakat setempat.

Seiring dengan kemajuan jaman dan era keterbukaan komunikasi, makanan tradisional juga mengalami dampak buruk globalisasi, yaitu terpinggirkan. Makanan tradisional mulai ditinggalkan oleh masyarakat lokal yang beralih ke makanan import. Oleh karena kondisi tersebut, maka perlu digalakkan lagi rasa cinta terhadap makanan tradisional, khususnya masyarakat Daerah Istimewa Yogyakarta yang menjadi sentral budaya Indonesia. Hal ini sesuai dengan ungkapan walikota Depok bahwa pangan lokal memiliki keunggulan tersendiri daripada pangan impor.

Gerakan mencintai makanan lokal (tradisional), harus terus digalakkan sebab makanan tradisional seperti jagung, ubi jalar, singkong, mbili, kimpul, ganyong, dan sejenisnya memiliki gizi tinggi. Disamping memiliki gizi tinggi, jugaalami karena tidak mengandung zat kimia. Sementara makanan sekarang justru berbahaya bagi kesehatan manusia, karena banyak mengandung zat kimia dan campuran bahan-bahan berbahaya (http: //www.suaramerdeka. com).

Makanan tradisional adalah makanan, minuman, makanan jajanan serta bahan campuran yang digunakan secara tradisional dan telah lama berkembang secara spesifik di daerah atau masyarakat Indonesia. Biasanya makanan tradisional diolah dari resep yang sudah dikenal oleh masyarakat setempat dengan bahan-bahan yang diperoleh dari sumber lokal yang memiliki citarasa yang sesuai dengan seleranya (http: //www.deptan.go.id). Kuhnlein and Receveur (Kwik, 2008) mendefinisikan makanan tradisional sebagai implikasi sebuah proses social kebudayaan seperti kutipan berikut.

"Traditionalfoodsystemsofindigenous peoples can be defined to items that are from the local, natural environment that are culturally acceptable. It also includes the sociocultural meanings, acquisition/ processing techniques, use, composition, and nutritional consequences for the people using the food" (Kuhnlein and Receveur, 1996).

Dari pengertian ini dan uraianuraian di atas, makanan tradisional tidak hanya berfungsi sebagai bahan makanan pokok yang dikonsumsi semata, tetapi juga mempunyai fungsi sosial, fungsi ritual, dan menjadi simbol identitas suatu masyarakat tertentu, dan pada kajian ini masyarakat Bantul khususnya.

Secara umum, sumber makanan terbagi menjadi dua golongan besar, yaitu makanan yang bersumber dari hewani dan makanan yang bersumber dari makanan hayati. Data dari Deptan (http: //www.deptan.go.id/pesantren/ bkp) menunjukkan bahwa ada empat kelompok pangan yang dikonsumsi masyarakat, yaitu kelompok pangan pokok, pangan tradisional, pangan lokal, dan pangan asli.

Pangan Pokok, adalah pangansumber karbohidrat yang sering dikonsumsi atau dikonsumsi secara teratur sebagai makanan utama, selingan, sebagai sarapan atau sebagai makanan pembuka atau penutup.Pangan Tradisional, adalah makanan yang dikonsumsi masyarakat golongan etnik dan wilayah yang spesifik, diolah dari resep yang dikenal masyarakat, bahan-bahannya diperoleh dari sumber lokal dan memiliki rasa yang relatif sesuai dengan selera masyarakat 
setempat. Pangan Lokal, adalah pangan yang diproduksi setempat (satu wilayah/ daerah) untuk tujuan ekonomi dan atau konsumsi. Pangan lokal tersebut berupa bahan pangan baik komoditas primer maupun sekunder. Pangan asli adalah pangan yang asal-usulnya secara biologis ditemukan di suatu daerah (http: // www.deptan.go.id).

Dari keempat kelompok tersebut, semuanyadapat dijadikan dasar untuk mendefinisikan makanan tradisional. Berdasarkan penjelasan tersebut makan-an tradisional adalah makanan yang dikonsumsi oleh etnik tertentu, dengan sumber bahan yang terdapat di sekitarnya, dibedakan menjadi makanan pokok dan selingan. Kelompok bahan pangan tradisional dapat dibedakan sebagai berikut: (a) jenis padi-padian meliputi beras, jagung, sorghum dan terigu; (b)jenis umbi-umbian meliputi: ubi kayu, ubi jalar, kentang, talas dan sagu; (c) jenis pangan hewani meliputi: ikan, daging, susu dan telur; (d) jenis minyak dan lemak meliputi: minyak kelapa, minyak sawit; (e) jenis buah/ biji berminyak yaitu kelapa daging; (f)jenis kacang-kacangan meliputi: kedelai, kacang tanah, kacang hijau; (g) gula meliputi: gula pasir, gula merah; (h) sayur dan buah meliputi: semua jenis sayuran dan buah-buahan yang biasa dikonsumsi; (i) jenis pangan yang lain antara lain: teh, kopi, coklat, bumbu-bumbuan, empon-empon, yang semuanya bisa jadi bahan makanan dan minuman.

\section{METODE}

Penelitian ini adalah penelitian survei, yang dilakukan di pasar-pasar tradisional di Kabupaten Bantul. Penelitian survei adalah penelitian yang mengumpulkan data pada saat tertentu dengan tiga tujuan penting, yaitu mendeskripsikan keadaan alami, mengidentifikasi secara terukur, dan menentukan hubungan sesuatu yang hidup (Sukardi, 2011). Tujuan penelitian untuk menginventarisasi jenis makanan tradisional di Kabupaten Bantul khususnya makanan tradisional yang berjenis jajan pasar. Adapun tujuan penelitian adalah sebagai berikut, (1) untuk mendeskripsikan jenis jajan pasar yang masih terjual di pasar-pasar tradisional Kabupaten Bantul, dan (2) untuk mendeskripsikan nama jajan pasar yang termasuk unsur sesaji di berbagai ritual Jawa.

Pendekatan teori yang digunakan dalam penelitian ini adalah pendekatan sosiokultural dan etnolinguistik. Sosiokultural adalah kajian yang berfokus pada kebiasaan hidup atau perilaku budaya suatu masyarakat. Masyarakat yang dirujuk dalam penelitian ini adalah masyarakat Jawa. Oleh karena itu tolok ukur atau parameter kevalidan direferensikan ke budaya Jawa, atau kebiasaan-kebiasaan hidup masyarakat Jawa.

Pendekatan etnolinguistik adalah pendekatan teori yang merujuk pada derivasi bahasa melalui perilaku budaya masyarakat pemakai bahasa yang dikaji. Dalam penelitian ini bahasa dan budaya yang diacu adalah budaya dan bahasa Jawa. Berdasarkan uraian tersebut maka pemaknaan benda atau sign dari jajan pasar yang terinvetarisasi didasarkan pada kebiasaan hidup dan kebiasaan berbahasa masyarakat Jawa.

Penelitian ini dilakukan di pasar tradisional di Kabupaten Bantul. Jumlah pasar tradisional yang teridentivikasi ada 29 pasar. Namun berdasarkan data yang diperoleh, ada dua buah pasar yang tidak bisa menjadi lokasi penelitian 
karena pasar tersebut adalah pasar hewan, yaitu: (1) Pasar hewan Pandak dan (2) Pasar hewan Imogiri. Rincian nama-nama pasar tersebut dapat dilihat di bawah ini (Kantor Pengelolaan Pasar Kabupaten Bantul, 2010).

\section{HASIL DAN PEMBAHASAN}

Hasil survei di 27 pasar tradisional di Kabupaten Bantul terindentivikasi dan teriventaris sebanyak 45 jenis makanan kecil tradisional atau jajan pasar. Makanan tersebut dikategorikan menjadi 5 ketegori yaitu makanan yang terbuat dari singkong dan ubi jalar, makanan yang terbuat dari beras, makanan yang terbuat dari jagung, makanan yang terbuat dari umbi-umbian, dan makanan yang terbuat dari kacangkacangan serta bahan baku lain seperti gandum, rumput laut dan lain sebagainya. Jajan pasar diolah dengan tiga teknik tradisional yaitu direbus dan dikukus, digoreng, dan dibakar.

Jajan pasar yang terinventarisasi juga masih digunakan sebagai ubarampe sajen pada ritual tertentu. Jenis jajan pasaryang banyak digunakan untuk sajen antara lain apem, ketan, kolak, lemper, jadah, wajik, jenang-jenangan, pala kependhem kukus/rebus, sedangkan jenis lain muncul secara kebetulan jika dibeli dan dijadikan unsur sesaji yang lazim disebut tukon pasar atau sesaji hasil belanjaan di pasar. Agar ada gambaran jenis makanan hasil survei, makaberikut ini akan disajikan beberapa sampel jajan pasar dari berbagai bahan bakunya.

\section{Beberapa Contoh Jenis Jajan Pasar Di Pasar-pasar Tradisional Kabupaten Bantul}

Jenis Makanan Tradisional yang Terbuat dari Bahan Baku Singkong dan Ubi Jalar

Berdasarkan hasil survei, makanan tradisional yang terbuat dari bahan baku singkong adalah: (1) Timus, (2) Gethuk, (3) Cenil, (4) Thiwul Ayu, (5) Thiwul, (6) Gathot, (7) Gethuk Goreng, (8) Lenthuk, (9) Sawut, (10) Lemet, dan (11) Growol. Makanan-makanan tersebut diolah dengan cara dikukus dan digoreng.

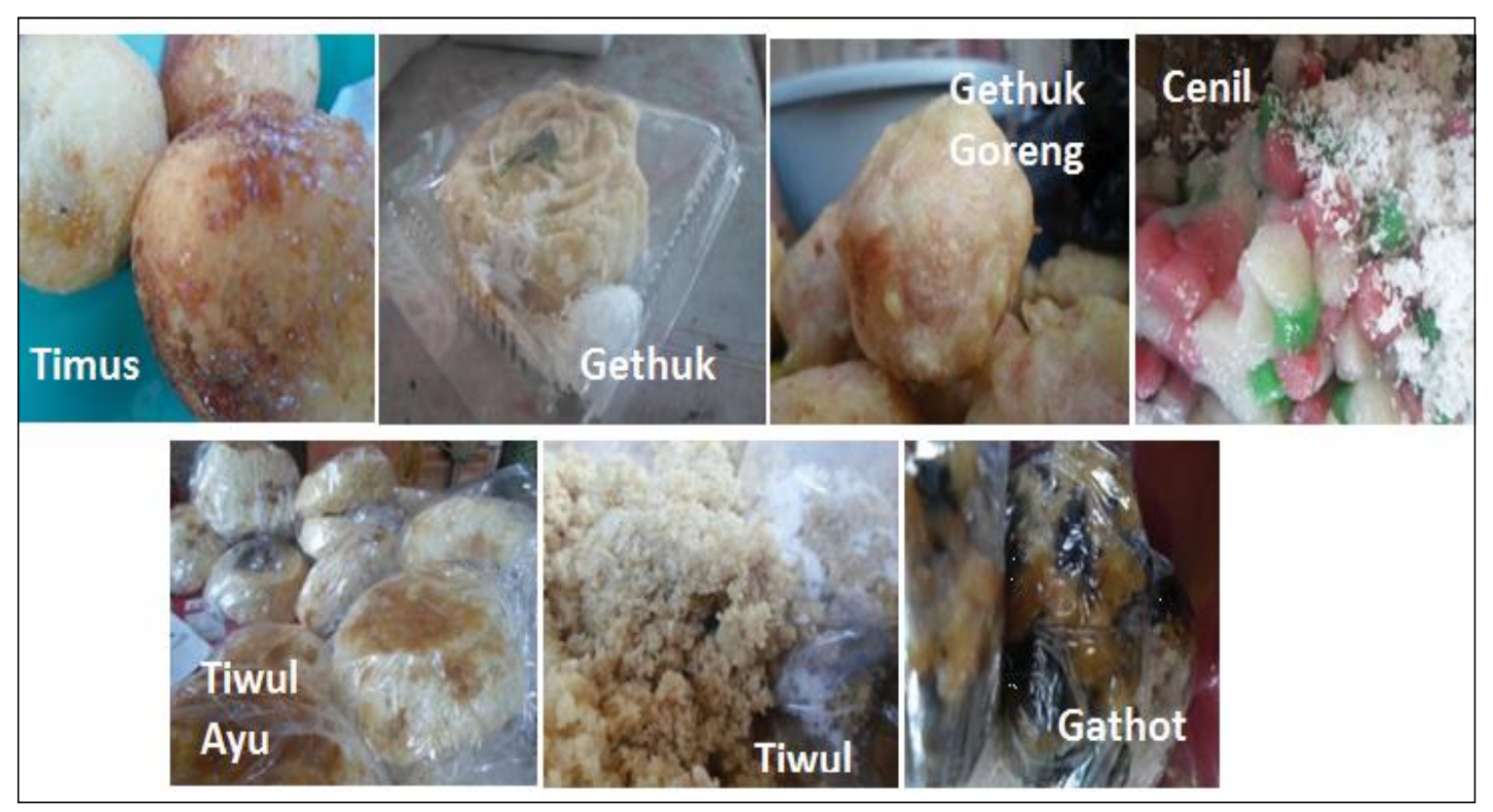

Gambar 1. Jenis Makanan Tradisional yang Terbuat dari Singkong dan Ubi Jalar 
Penjelasan rinci cara pengolahan, dan bahan-bahannya dengan contoh beberapa jenis makanan adalah sebagai berikut.

\section{Timus}

Bahan baku untuk membuat Timus adalah ubi jalar. Bahan yang lain berupa: gula pasir, kelapa parut, garam, tepung kanji/pati singkong, dan minyak goreng. Peralatan yang dibutuhkan adalah pisau, soblok untuk mengukus, lumpang dan alu untuk menumbuk.

Cara mengolah: kupas ubi jalar, cuci bersih, lalu kukus. Setelah ubi jalar matang ditumbuk halus, tambahkan bahan yang lain campur rata. Adonan berikutnya dibentuk/dicetak oval dengan ukuran dalam kepalan tangan orang dewasa, lalu digoreng hingga warna kuning keemasan, angkat tiriskan. Olahan ini siap dipasarkan.

Timus di jual perbiji berkisar antara Rp. 500,- hingga Rp. 1000,-. Nilai ekonomis penjualan Timus, jika dibanding dengan makanan modern terbilang masih sangat murah. Makanan modern yang beredar di pasar yang sama, bernilai jual lebih tinggi, rata-rata di atas Rp. 2000,- Dengan demikian dapat diambil kesimpulan bahwa makanan tradisional perlu diupayakan cara untuk mengembangkan ke kualitas yang lebih baik agar memiliki daya saing dan daya jual tinggi, setidaknya sama dengan makanan modern yang beredar di pasar yang sama. Makanan ini ditemukan di seluruh pasar yang disurvei.

\section{Gethuk}

Bahan baku untuk membuat Gethuk adalah singkong. Bahan yang lain adalah: garam dan kelapa parut, serta gula Jawa untuk gethuk manis, Gethuk Ayu, dan Gethuk Lindri. Peralatan yang diperlukan adalah pisau, soblok atau alat pengukus, alat penumbuk, gilingan daging untuk Gethuk Lindri, dan tambir atau tampah.

Cara mengolah: kupas singkong, cuci bersih, lalu dikukus. Setelah matang, singkong ditaburi garam secukupnya, dan ditumbuk halus. Hasil tumbukan diratakan di tambir atau nyiru. Gethuk siap dipasarkan dan penghidangannya dengan ditaburi kelapa parut.

Gethuk Manis, Gethuk Ayu, dan Gethuk Lindri, dalam menumbuk ditambahkan gula Jawa atau gula pasir sesuai keperluan. Gethuk Manis ditumbuk sampai halus saja, sehingga teksturnya halus dan tidak sangat pekat. Berbeda dengan Gethuk Manis, Gethuk Ayu ditumbuk sampai pekat, sehingga bertekstur halus pekat/alot. Berikutnya, untuk Gethuk Lindri cara menghaluskannya menggunakan alat penggiling daging. Hasilnya dipotongpotong sekitar 4 sampai $5 \mathrm{~cm}$. Gethuk Lindri biasanya diberi warna merah, cokelat, kuning dan hijau. Gethuk Lindri dihidangkan dengan ditaburi kelapa parut, atau kelapa parut yang dicampur gula pasir. Gethuk-gethuk tersebut siap dipasarkan. Secara nilai ekonomis Gethuk Lindri dan Gethuk Ayu, memiliki daya jual tinggi dibanding gethuk yang lainnya. Hal ini disebabkan tampilan dan tambahan bahan yang lain. Gethuk dijual diseluruh pasar yang disurvey, kecuali Gethuk Ayu hanya ditemukan di Pasar Bantul dan Pasar Ngipik.

\section{Gethuk Goreng}

Bahan baku sama dengan Gethuk yang lain, dan ditambah tepung terigu dan minyak goreng.

Cara mengolah, sama Gethuk Ayu. Hasil tumbukan dicetak bulat-bulat sebesar kelereng dan digoreng. Hasilnya siap dipasarkan. 
Gethuk goreng dibanding dengan gethuk lainnya memiliki harga jual yang lebih tinggi, karena proses pembuatannya lebih lama, serta dibutuhkan bahan tambahan minyak goreng. Gethuk Goreng tidak ditemukan di Pasar Pundong. Hal ini disebabkan pedagangnya tidak berjualan di pasar lain, sedangkan pedagang lain mengatakan terlalu ribet untuk membuat, dan membutuhkan waktu lama. Pembelinya pun tidak terlalu banyak.

\section{Cenil}

Bahan baku untuk membuat Cenil adalah: tepung kanji, gula pasir, kelapa parut, garam, dan pewarna makanan. Peralatan yang dibutuhkan adalah panci pengukus, baskom, dan nampan.

Cara mengolah: campurtepung kanji, gula pasir dan sedikit garam, kemudian diberi air sedikit demi sedikit dan diuleni sampai kalis. Bentuk bulat-bulat kecil, dan dikukus. Cara penghidangan taburi cenil dengan kelapa parut.

Cenil ditemukan di semua pasar yang disurvei. Makanan ini memiliki harga jual yang relatif sama, antara Rp.500,sampai Rp.1000.- untuk wilayah kota seperti Pasar Bantul dan Niten. Meskipun demikian di Niten masih melayani harga Rp.500,- karena kasihan, atau tidak tega, apalagi pelanggan. Makanan ini terjual diseluruh pasar yang disurvei.

Jenis Makanan Tradisional yang Terbuat dari Bahan Baku Tepung Beras

Berdasarkan hasil survei, makanan tradisional yang terbuat dari bahan baku tepung beras adalah: (1) nagasari, (2) lapis, (3) apem, (4) adrem, (5) srabi, (6) cara, (7) jenang sum-sum, (8) jenang abang, (9) cucur. Makanan-makanan tersebut

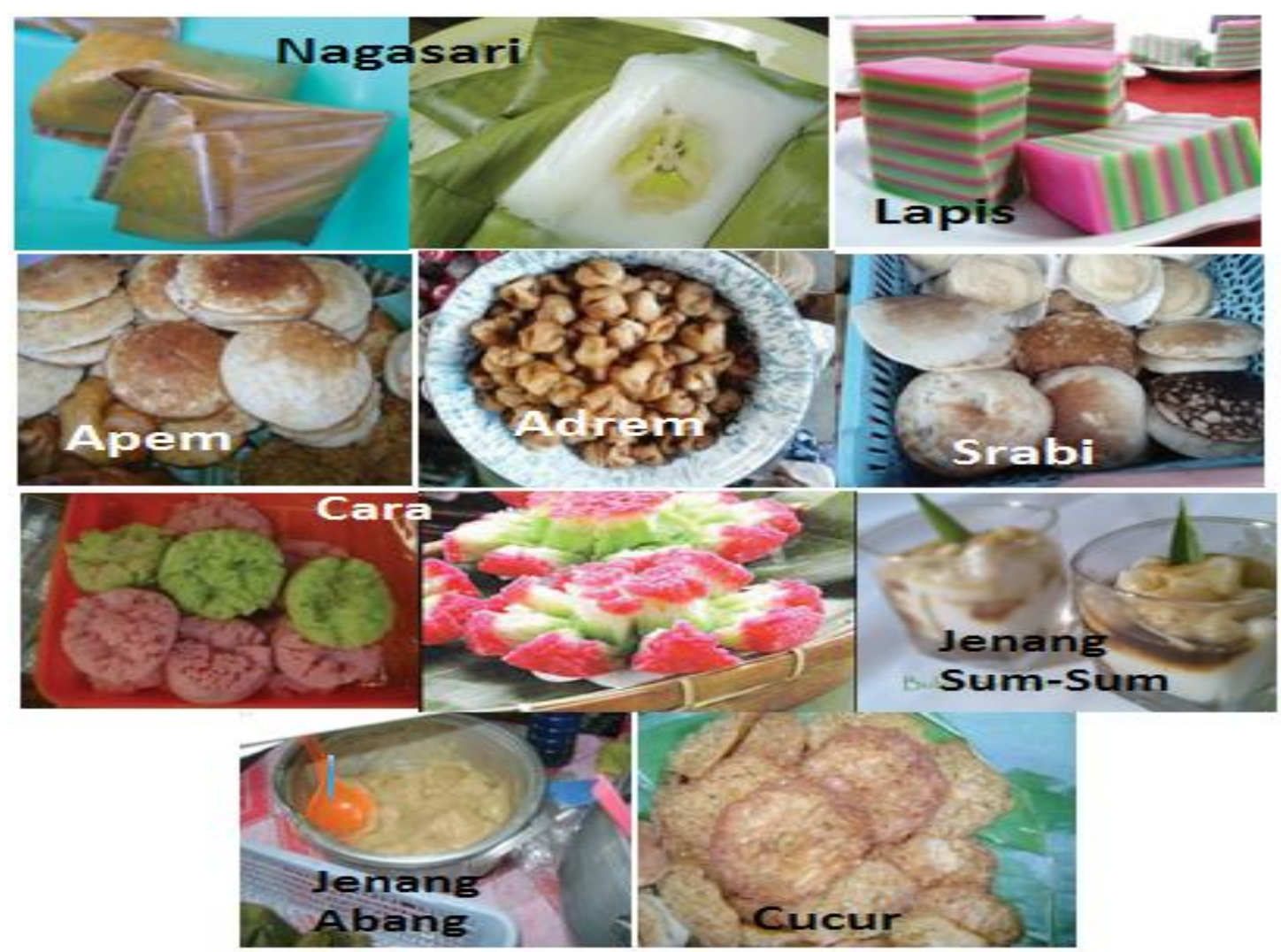

Gambar 2. Jenis Makanan Tradisional yang Terbuat dari Tepung Beras 
diolah dengan cara dikukus dan digoreng. Penjelasan rinci cara pengolahan, dan bahan-bahannya dari beberapa jenis yang dicontohkan adalah sebagai berikut.

\section{Nagasari}

Nagasari adalah sejenis kue tradisional yang terbuat dari bahan baku utama tepung beras. Kue ini cukup terkenal sehingga seringkali disajikan dalam acara-acara pertemuan. Nagasari juga merupakan salah satu kue basah yang kerap menjadi bagian dalam upacara tradisional Jawa seperti upacara bakti kepada leluhur. Kue ini dimasak dengan cara dikukus. Selain sebagai nama makanan, nagasari juga merupakan nama dari salah satu motif batik. Nama nagasari (Palaquium rostratum) juga diabadikan sebagai nama pohon suci yang kayunya dipercaya dapat memberikan manfaat perlindungan dari roh jahat, dan tenung. Juga bermanfaat untuk keselamatan dan kewibawaan.

Bahan baku untuk membuat Nagasari adalah: gula pasir, tepung beras, tepung tapioka, santan, garam secukupnya, daun pandan, pisang raja, dan daun pisang.

Cara membuat kue Nagasari: masak santan, daun pandan, dan gula sampaigula meleleh, larutkan tepung beras dengan sedikit air, masukkan dalam campuran santan, masak diatas api kecil, aduk terus sampai setengah matang dan mengental, angkat adonan, ambil selembar daun pisang, taruh beberapa sendok adonan. Letakkan potongan pisang di tengahtengah adonan dan tutup lagi dengan adonan, bungkus rapi, kemudian lipat bagian ujung daun pisang, kukus selama 45 menit.

Pembuatan kue nagasari yang dijual di pasar-pasar di Kabupaten Bantul, umumnya masih menggunakan cara tradisional dan dibuat oleh industri rumahan. Alat-alat yang digunakan cukup sederhana, antara lain: baskom, soblok (alat pengukus tradisional), dan kompor. Daya jual pedagang di pasar tradisional untuk kue ini antara 2030 buah/hari. Untuk kue tradisional yang dijual di pasar, bahannya belum menggunakan bahan tambahan. Akan tetapi pada masa sekarang ini, bahan pembuat nagasari dapat diganti dengan tepung hankue agar lebih kenyal. Selain itu, santan juga seringkali diganti dengan susu rendah lemak. Berdasarkan hasil wawancara dengan para produsen nagasari, disebutkan bahwa kue ini tidak diberi bahan tambahan seperti pengawet maupun pewarna.

\section{Kue Apem}

Kue apem adalah sejenis kue tradisional yang terbuat dari bahan baku utama tepung beras. Kue ini populer di kalangan orang Jawa. Di tengahtengah maraknya industri bakery, kue apem tetap bisa bertahan dikarenakan rasanya yang khas. Tekstur yang empuk dan lembut juga merupakan daya tarik jajanan tradisional ini. Selain dari segi rasa, kue apem juga mempunyai makna yang penting bagi masyarakat Jawa.Apem dipercaya berasal dari kata dari bahasa Arab afuum yang berarti pemberian maaf (ampunan) atau pengayoman.

Oleh karena itu, apem akrab dengan orang Jawa, karena kue ini bukan saja dipandang sebagai makanan, tetapi juga sebagai bentuk doa untuk memperoleh pengampunan dan pengayoman.Hampir semua ritual upacara tradisional Jawa menggunakan apem sebagai sesajian. Misalnya dalam upacara selama masa kehamilan, upacara tradisional sunatan, upacara pernikahan, sampai upacara kematian. Bahkan tradisi-tradisi unik di Jawa juga terkait dengan kue ini. Misalnya upacara ngapem di lingkungan 
kraton Yogyakarta yang dipimpin oleh permaisuri Sultan Hamengkubuwana. Terdapat pula upacara Ruwahan yang kegiatan utamanya membuat kue apem. Ruwahan dilaksanakan menjelang bulan Ramadhan. Apem pada upacara ini bermakna permohonan ampun agar bersih dari dosa, sebelum menjalankan ibadah puasa. Selain itu terdapat pula upacara sebar apem yang dikenal dengan nama Upacara Yaa Qo Wi Yuu. Pada upacara ini disebar kurang lebih 4 ton apem yangdiperebutkanolehpengunjung.Apem yang didapat pada upacara ini dipercaya mempunyai khasiat dapat menyuburkan tanah, melariskan jualan, dan lain-lain.

Bahan untuk membuat apem adalah: tepung beras, tepung kanji, gula pasir, santan, ragi, garam secukupnya, satu butir telur, kelapa parut.

Cara membuat kue apem: Semua bahan (kecuali minyak/mentega) dicampur menjadi satu dan di beri air secukupnya. Campurkan sedikit demi sedikit sampai menjadi adonan yang bisa dibentuk. Dicampur sampai lembut. Pukul-pukul adonan selama 15 menit. Masukkan telur dan kelapa parut. Adonan diaduk dan di diamkan (kurang lebih 1 jam) sampai mengembang. Adonan dituangkan ke cetakan kemudian dibakar. Cetakan dalam keadaan panas dan sudah di olesi minyak/mentega.

Pembuatan kue apem yang dijual di pasar-pasar di Kabupaten Bantul, umumnya masih menggunakan cara tradisional dan dibuat oleh industri rumahan. Alat-alat yang digunakan cukup sederhana, antara lain: Cetakan alumunium, sothil (spatula) ukuran kecil, dan kompor minyak. Daya jual pedangang di pasar tradisional untuk kue ini kurang lebih $10 \mathrm{~kg} /$ hari atau setara dengan 40 buah apem/ hari.

\section{Jenang Sumsum}

Jenang sumsum adalah makanan tradisional yang termasuk jenis bubur. Jenang sumsum dikenal luas dan termasuk makanan tradisional yang sampai sekarang masih menjadi favorit. Untuk memasak jenang sumsum, diperlukan ketelitian dan kesabaran agar teksturnya halus dan cita rasanya gurih. Jenang sumsum juga banyak digunakan dalam upacara tradisional Jawa seperti upacara tingkeban, pernikahan adat Jawa, dan lain-lain.

Bahan Jenang sumsum: tepung beras, daun pandan (bersihkan dan sobek lalu simpul), santan kental (hasil parutan 1 butir kelapa tua), garam. Bahan kuah: air bersih, gula merah (disisir halus), daun pandan (bersihkan dan buat simpul).

Cara membuat jenang: bagilah santan ke dalam dua wadah yang berbeda, panaskan santan pada wadah pertama bersama dengan simpulan daun pandan menggunakan api kecil sambil terus diaduk, jangan sampai santan pecah. Santan pada wadah kedua dicampur dengan tepung beras dan garam, adukaduk hingga semua bahan tercampur rata. Kemudian tuangkan pada wadah kedua kedalam campuran santan pada wadah pertama yang sedang dipanaskan, aduk-aduk terus kedua campuran hingga menjadi bubur yang kental. Setelah dirasa cukup matang segera angkat dan biarkan dingin.

Cara membuat kuah: campurkanlah air bersama gula serta daun pandan dan aduk-aduk hingga menyatu dan rata. Kemudian rebuslah campuran gula dengan menggunakan api sedang hingga mengental, jika dirasa cukup segera angkat dan sisihkan hingga dingin.

Jenang sumsum yang dijual di pasar-pasar tradisional di Kabupaten 
Bantul umumnya masih menggunakan cara tradisional dan dibuat oleh industri rumahan. Jenang ini tidak banyak mengalami perubahan bentuk maupun cara penyajian. Alat-alat yang digunakan dalam proses pembuatan jenang sumsum masih cukup sederhana, antara lain: Sendok sayur, panci, ayak, dan parut. Daya jual pedagang di pasar tradisional untuk kue ini biasanya mencapai $1,5 \mathrm{~kg}$ per hari dengan rata-rata keuntungan Rp. 25.000,-, dengan modal Rp. 150.000,--

\section{Jenang Abang}

Jenang abang, seperti halnya jenang sumsum, juga termasuk makanan tradisional yang sejenis bubur. Jenang abang dikenal luas dan termasuk makanan tradisional yang sampai sekarang masih menjadi favorit. Untuk memasak jenang abang, diperlukan ketelitian dan kesabaran agar teksturnya halus dan cita rasanya gurih. Jenang abang juga banyak digunakan dalam upacara tradisional Jawa seperti upacara kelahiran, pernikahan adat Jawa, dan lain-lain.

Bahan-Bahanyangdibutuhkan: gram beras, santan encer, santan kental, gula merah sisir, daun pandan yang dibentuk simpul, garam secukupnya.

Cara membuat: masaklah beras dicampur dengan santan encer, garam dan daun pandan hingga mengental menjadi bubur. Jika sudah tuangkan santan yang kental tunggu beberapa saat kemudian angkat. Tambahkan sisiran gula merah aduk hingga warnanya berubah.

Jenang abang yang dijual di pasarpasar tradisional di Kabupaten Bantul umumnya masih menggunakan cara tradisional dan dibuat oleh industri rumahan. Jenang ini tidak banyak mengalami perubahan bentuk maupun cara penyajian. Alat-alat yang digunakan dalam proses pembuatan jenang abang masih cukup sederhana, antara lain: Sendok sayur, panci, ayak, dan parut. Daya jual pedagang di pasar tradisional untuk kue ini biasanya mencapai $1,5 \mathrm{~kg}$ per hari dengan rata-rata keuntungan Rp. 25.000, dengan modal Rp. 150.000,-.

Jenis Makanan Tradisional yang Terbuat dari Bahan selain Singkong dan Beras

\section{Tempe Benguk, Tempe Kara, Tempe Gembus, dan Tempe Kedelai}

Bahan baku pembuatan tempe benguk, kara, gembus, dan kedelai adalah kacang benguk, kacang kara, kacang kedelai, kedelai, ampas tahu. Alat yang diperlukan adalah panci untuk merebus, tenggok untuk menginjak saat membersihkan kulitnya, tambir, atau tampah pisau dan telenan untuk memotong benguk. Daun pisang untuk membungkus.

Cara pembuatan: kukus benguk, kara atau kedelai sampai empuk. Bersihkan kulitnya dengan cara menginjak-injak. Rendam kacang kara, dan potongan benguk yang sudah bersih selama sehari semalam dengan berkali-kali mengganti air agar racunnya hilang. Hari kedua kacang kara, benguk, kedelai direbus, setelah empuk diangkat, ditiriskan, didinginkan lalu diusari/diberi ragi tempe sampai rata. Kacang yang sudah diberi ragi lalu dibungkus dengan daun pisang. Bungkusan kacang ditutup kain atau dikumpulkan agar hangan semalam, pagi lepas kerukupnya dan diurai. Sore tempe sudah jadi. Proses pembuatan Tempe Gembus sama seperti tempe yang lain. Ampas tahu dikukus, setelah matang didinginkan dan diberi ragi lalu dibungkus dengan daun, ditutup kain atau penutup yang lain semalam, diurai dan paginya tempe siap diolah. 

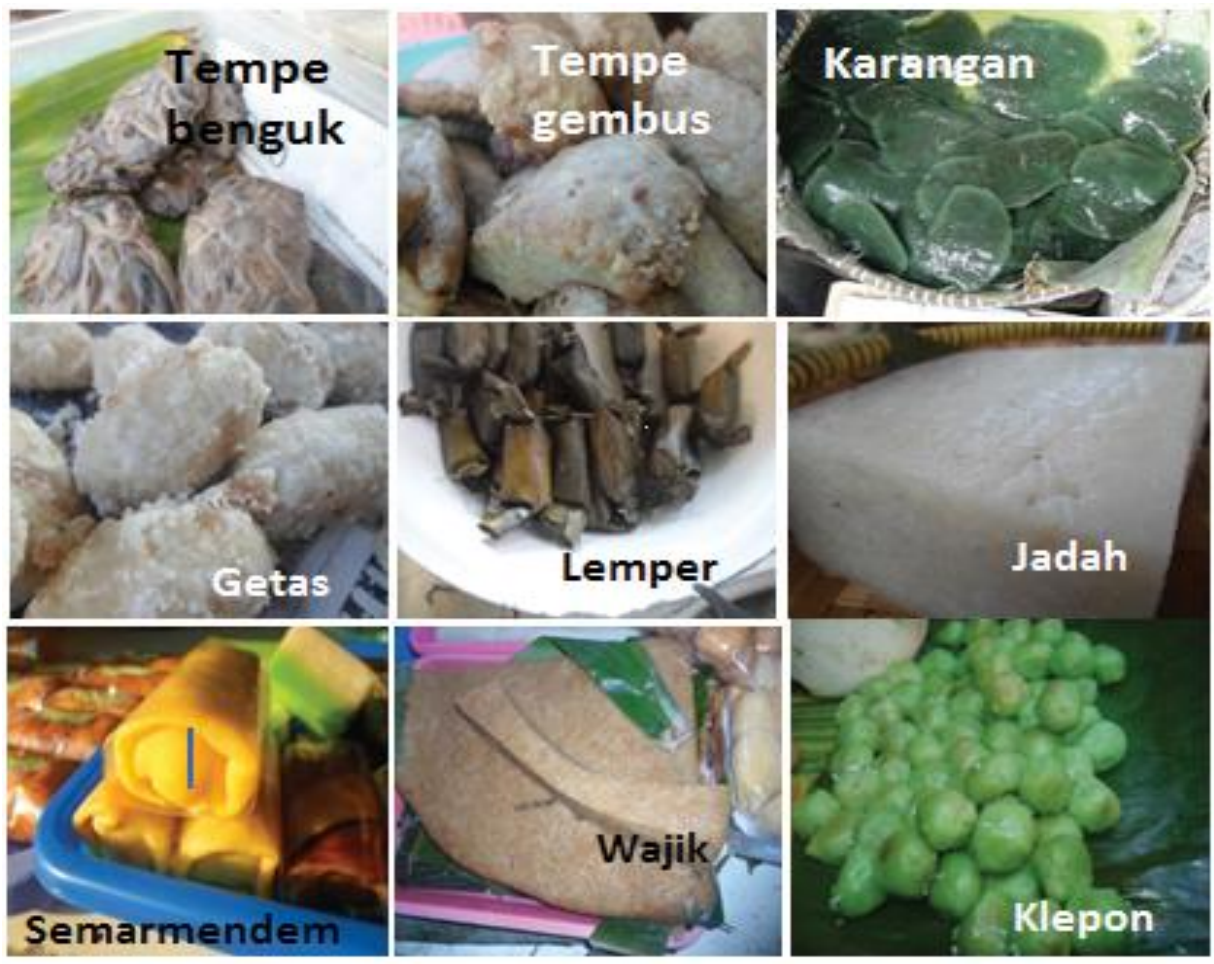

Gambar 3. Jenis Makanan Tradisional yang Terbuat dari Bahan selain Singkong dan Beras

Cara membuat tempe bacem: rebus tempe dengan air kelapa, gula Jawa, bawang putih, bawang merah, ketumbar, salam, daun jeruk purut, jahe, dan garam, sampai agak kering. Jika sudah dingin tempe digoreng, dan siap dipasarkan.

Cara membuat tempe besengek: masak tempe dengan santal kental, bawang putih, bawang merah, ketumbar, miri, salam, daun jeruk purut, sereh, gula Jawa, masak sampai empuk dan kuah tinggal sedikit. Tempe besengek siap dipasarkan. Berdasarkan hasil survei tempe kedelai bacem ditemukan disemua pasar, sedangkan tempe benguk ditemukan di pasar Turi, Celep, Ngangkruk, Mangiran, Gathak, Pundong dan Niten. Harga jual pertempe kedelai Rp.500,- sampai Rp.1000,-, sedangkan tempe kara dan benguk Rp. 500,- perbiji. kemampuan jual setiap hari sekitar 50 buah, sehingga nilai ekonomi yang didapat berkisar Rp. 25000,- sampai Rp. 50.000,-. Tempe kedelai dan Tempe Gembus, dalam perkembangannya diolah dengan adonan terigu dan terkenal dengan nama tempe kemul. Tempe ini memiliki harga jual rata-rata Rp.1000,perbiji.

\section{Karangan}

Bahan baku Karangan adalah rumput laut basah. Alat yang dibutuhkan adalah panci untuk memasak dan cetakan.

Cara mengolah: rumput laut dicuci bersih, lalu dimasak dengan air sampai hancur dan menjadi bubur. Bubur rumput laut dicetak dengan batok tipis, setelah dingin dilepas, bentuknya mirip gula Jawa. karangan biasanya dimakan dengan Kethak Nyunyuk dan lombok hijau, atau Kethak Nyunyuk disambal bawang. Karangan kalau dimakan 
tanpa kethak rasanya tawar agak amis. Karangan dijual perbiji seharga Rp.500,saja. Makanan ini terdapat di pasar yang dekat pantai selatan, yaitu pasar Pundhong, Ngangkruk, Turi, Celep, dan Sorobayan.

Makanan ini juga tidak setiap saat bisa ditemukan, karena rumput laut bisa dipetik pada musim-musim tertentu. Rumput laut sebetulnya bisa dibuat camilan yang berdaya jual tinggi. Caranya dengan merubah cara masak. Misalnya: digoreng dengan tepung terigu, dan bumbu krispi, hasilnya menjadi rumput laut krispi. Rumput laut krispi telah diproduksi di wilayah Baron dan sekitarnya. Harga perkilogram mencapai Rp.50.000,-. Cara ini yang perlu disosialisaikan di wilayah Bantul, agar pedagang Karangan, bisa meraih nilai jual rumput laut lebih tinggi.

\section{Monte}

Bahan baku Monte adalah sagu mutiara, gula pasir, kelapa parut. Alat yang diperlukan adalah panci pengukus, daun pisang, tusuk gigi.

Cara mengolah: rendam sagu mutiara selama 2 sampai 3 jam lalu diangkat dan ditiriskan. Campur kelapa parut, gula pasir dan sagu mutiara, aduk rata. Adonan kemudian dibungkus daun pisang, lalu dikukus sampai matang. Monte perbungkus dijual Rp.1000,Monte sebetulnya bukan makanan khas Jawa. Orang Jawa tidak berbudaya makan sagu. Seiring meluasnya jangkauan dagang antarwilayah, maka sagu akhirnya dikenal orang Jawa, tidak terkecuali sagu mutiara. Olahan sagu diberlakukan sama dengan model olahan bahan baku setempat, yang rata-rata dicampur gula dan kelapa. Hasil survei, Monte dijual diseluruh pasar di Kabupaten Bantul. Nilai ekonomi penjualan Monte, tidal terlalu beda dengan makanan yang lainnya. Perhari rata-rata terjual antara 30 sampai 50 bungkus. Untuk menaikan nilai ekonomi, sagu mutiara bisa diolah dengan tepung Hung Kwe, hasilnya berupa puding. Puding dijual lebih mahal dari pada Monte. Harga puding dapat mencapai Rp.2.500,- hingga Rp. 3.000,perbiji.

\section{Hawuk-hawuk}

Bahan bakunya adalah tepung ketan, kelapa parut, gula pasir, pewarna makanan. Peralatan yang dibutuhkan yaitu panci pengukus, tambir, dan baskom.

Cara mengolah: semua bahan dicampur rata, lalu dikukus. Setelah matang dituang di tambir yang dialasi daun pisang lalu dipadatkan. Setelah dingin makanan ini dipotong-potong. Hawuk-hawuk dijual perpotong Rp.1.000,-. Kemampuan jual Hawukhawuk rata-rata perhari satu tambir atau sekitar 50 potong, sehingga nilai uang yang bisa didapat sekitar Rp. 50.000,. Hawuk-hawuk dijual di pasar Niten, Argamulya, dan Bantul. Adonan hawukhawuk sebetulnya bisa diolah dengan cara dibakar. Olahan ini dinamakan Sagon. Cara membakar bisa dengan cobek, atau dioven untuk cara yang lebih modern. Olahan sagon memiliki daya jual lebih tinggi. Sagon tradisional dijual Rp. 2000,- perbiji. Untuk sagon oven perloyang biasa dijual Rp. 25.000,- sampai Rp. 30.000,-.

\section{Lemper}

Bahan baku untuk membuat Lemper adalah ketan. Bahan yang lain berupa: daging ayam, santan, bawang merah, bawang putih, daun jeruk, garam, dan minyak goreng. Peralatan yang dibutuhkan adalah pisau, soblok untuk mengukus, wajan untuk menumis. 
Cara mengolah: cuci bersih ketan kemudian kukus sampai setengah matang. Setelah ketan dikukus campur ketan dengan santan dan garam sampai santan meresap, kukus kembali sampai ketan matang. Untuk membuat isian lemper panaskan minyak goreng, tumis bumbu yang telah dihaluskan kemudian masukkan daging ayam yang telah dicincang dan tambahkan santan, masak sampai matang. Bungkus ketan yang telah diisi dengan isian Lemper dengan daun pisang. Kukus kembali ketan yang telah dibungkus dengan daun pisang sampai matang. Makanan ini ditemukan diseluruh pasar yang di survey. Lemper merupakan makanan tergolong mewah. Lemper biasa dihidangkan pada hajatan. Harga jual lemper termasuk tinggi, perbiji dijual Rp. 1.500,- sampai Rp. 2.000,-. Daya jual Lemper tergantung bulan baik. Untuk bulan Besar, Lemper banyak dipesan oleh pembeli. Saat seperti ini omset penjualan bisa mencapai 300 bahkan sampai 500 buah. Waktu seperti ini biasanya keuntungan bisa dirasakan.

\section{Jadah}

Bahan baku untuk membuat Jadah adalah ketan. Bahan yang lain adalah: kelapa parut, garam, dan air. Peralatan yang diperlukan adalah pisau, parut, soblok atau alat pengukus, dan alat penumbuk.

Cara mengolah: cuci bersih ketan kemudian kukus sampai setengah matang. Campur ketan yang telah dikukus setengah matang dengan air panas, garam, dan kelapa parut, kemudian aduk sampai rata dan air terserap ketan. Kemudian kukus kembali ketan samapai matang. Keluarkan ketan yang sudah matang dari kukusan, tumbuk selagi masih dalam keadaan panas hingga ketan menjadi halus dan liat dan padat. Ambil kira-kira 2 sendok makan ketan, buatlah bentuk bulat, lalu dipipihkan setebal kira-kira $1 \frac{1}{2} \mathrm{~cm}$. Makanan ini ditemukan diseluruh pasar yang di survey. Jadah biasa dijual Rp. 500,- untuk potongan kecil dan Rp. 1.000,- untuk potongan besar. Rata-rata penjualan mencapai 75 sampai 100 potong. Jadah biasa dipesan para pedagang sayur keliling, sehingga daya jual relatif stabil jumlahnya.

\section{Wajik}

Bahan untuk membuat Wajik adalah ketan. Bahan yang lain berupa: santan, gula Jawa, air, daun pandan, dan garam. Peralatan yang dibutuhkan adalah soblok untuk mengukus, panci, baskom, dan loyang.

Cara mengolah: cuci bersih ketan kemudian kukus sampai setengah matang. Kemudian angkat ketan setengah matang dan rendam ketan kira-kira 10 menit di dalam air mendidih yang telah disiapkan, selanjutnya kukus kembali ketan hingga matang. Masak santan bersama gula merah, daun pandan dan garam sambil diaduk-aduk hingga kental. Masukkan ketan yang sudah matang ke dalam larutan santan dan aduk sampai rata. Kemudian masak hingga larutan santan dan gula merah terserap merata ke dalam ketan dan dikukus. Siapkan loyang persegi empat kemudian olesi cetakan dengan menggunakan minyak goreng, tuangkan adonan wajik kedalam loyang tersebut dan dinginkan. Setelah adonan wajikdingin, potong-potong bentuk persegi. Makanan ini dijual diseluruh pasar yang disurvey. Wajik dan Jadah merupakan makanan satu kesatuan. Wajik dan Jadah, biasa dijual Rp. 500,- untuk potongan kecil dan Rp. 1.000,- untuk potongan besar. Ratarata penjualan mencapai 75 sampai 100 potong. Jadah dan wajik biasa dipesan para pedagang sayur keliling, sehingga daya jual relatif stabil jumlahnya. 


\section{Jajan Pasar yang termasuk Unsur Sesaji}

Tradisi ritual Jawa terdiri dari ritual sebelum kelahiran, setelah lahir, dan kematian. Ritual sebelum kelahiranyang lazim diselenggarakan adalah nglimani atau upacara lima bulan kehamilan/ tingkeban atau upacara tujuh bulan kehamilan, dan dalam perkembangan karena pengaruh Islam diselenggarakan upacara empat bulan kehamilan (Suwondo, 1982). Ritual pasca kelahiran atau setelah lahir meliputi upacara brokohan, sepasaran, puput ataupupak puser, selapanan, bancakan setiap hari kelahiran, tetesan, supitan/sunatan, taraban, dan upacara pernikahan. Upacara kematian meliputi surtanah, telung dina, pitung dina, patang puluh dina, satus dina, setaun, mendhak/rong taun, sewu dina, kol, dan nyadran. Rituaritual tadi diistilahkan dengan singkatan tiga M, yaitu metu, manten, dan mati.

Ritual di atas diselenggarakan dengan maksud untuk mengucap rasa syukur kepada Sang Pencipta atas semua kebaikan yang telah dilimpahkan dan permohonan, serta doa kepadaNya untuk memohon keselamatan dan kelancaran hidupnya. Dalam tradisi Jawa semua ritual biasa dilengkapi sesaji. Sesaji Jawa berdasarkan jenisnya dibedakan menjadi sesaji makanan dan non makanan. Sesaji makanan dibedakan menjadi makanan utama yang berupa nasi dan dan lauk, aneka jenang, aneka makanan kecil atau jajan pasar, buahbuahan, dan hasil bumi yang lain seperti pala kependhem dan pala kesampar. Sesaji non makanan antara lain berupa bunga, daun-daunan, pepohonan, rokok dan kinang, dan peralatan rumah tangga.

Sesaji makanan utama lazimnya disebut ambengan, biasanya terdiri dari tumpeng, sega golong, dan aneka lauk pauk sesuai jenis selamatan yang diselenggarakan. Sesaji jenang berupa jenang abang, putih, sungsum, dan barobaro, jenang seger, jenang legen, jenang tuwa, dan jenang manca warna (Baihaqie, 2014: 69), sedangkan sesaji yang berupa makanan kecil, buah-buahan, dan hasil bumi disebut tukon pasar. Sesaji ini terdiri dari jajan pasar, aneka buah, dan olahan aneka hasil bumi yang berupa pala kependhem atau makanan yang berupa umbi-umbian atau tanaman yang buahnya terpendam. Wujud makanan tersebut antara lain ketela rambat, gembili, gembolo, uwi, ketela puhung, suweg, dan kentang (Suwandi, 2003: 29). Hasil bumi yang tergantung dinamakan pala gumantung, berupa kates, mangga, jeruk, pisang dan lain sebagainya.Adapun hasil bumi yang terserak disebut pala kesampar. Pala kesampar berupa labu kuning, mentimun, melon, semangka, dan krai (Suwandi, 2003: 31). Mentimun dan krai memiliki jenis terserak dan tergantung. Jenis mentimun dan krai yang besar buahnya biasanya buahnya terserak.

Sesaji tukon pasar adalah sesaji yang rangkaian unsurnya terdiri dari jajan pasar dan hasil bumi. Jajan pasar yang terdapat di pasar tradisional Bantul hampir semuanya dapat dijadikan unsur sesaji jenis tukon pasar. Dari 45 jenis jajan pasar yang ditemukan ada beberapa jenis yang memiliki tingkat keseringan muncul di sesaji. Makanan tersebut antara lain: apem, ketan, kolak, aneka jenang, jadah, wajik, lemper, dan olahan pala kependhem.

Apem ketan kolak merupakan makanan tiga serangkai. Makanan ini lazim muncul di dalam sesaji ritual kematian. Fungsi sesaji ini sebagai simbol permintaan maaf penyelenggara ritual kepada peserta ritual, permintaan maaf ahli waris yang diselamati kepada semua yang ada di ritual agar 
berkenan memaafkan almarhum atau almarhumah atas semua kesalahanya. Apem dietimologi primitifkan dari kata Arab afuwwyang berarti maaf, dari kata ini ucapan bergeser menjadi apem yang dilambangkan makanan yang disebut apem. Makanan ini semula dijadikan tanda (sign) kata apem, dan untuk memudahkan mengingat maksud tersebut dilambangkan kata tersebut dengan benda sebagai petanda (significatum) berupa makanan yang disebut apem. Makanan yang berujud kolak juga merujuk kata kata bahasa Arab qolayang artinya berkata. Serangkaian makanan tersebut mentradisi, dan dijadikan lambang ucapan/kata permohonan maaf kepada siapa saja yang hadir diritual yang diadakan.

Selamatan apem, ketan dan kolak yang sangat terkenal di Jawa diselenggarakan di bulan Ruwah, ritual ini disebut nyadran. Di Klaten Jawa tengah upacara sejenis dilakukan di bulan Sapar disebut upacara Jakawiyu. Apem jenis kocor yaitu apem dilengkapi juruh atau cairan yang terbuat dari gula merah dan santan, dihadirkan dalam sesaji ritual kandungan berusia empat dan enam bulan (Suwondo, 1982). Harapan dari sesaji ini adalah permohonan kepada Yang Maha Kuasa agar pertemuan sperma dan ovum atau lambang merah dan putih dari juruh tumbuh sehat dan menjadi janin yang kuat dan suci.

Makanan berikutnya yang banyak hadir di sesaji adalah aneka jenang. Jenang terdiri dari jenang sungsum yaitu jenang yang dijadikan simbol pemulihan kekuatan. Jenang ini disajikan pada pasca perhelatan. Semua orang yang terlibat dalam penyelenggaraan ritual disuguhi makanan tersebut agar kekuatan mereka pulih kembali. Dalam istilah Jawa pulih otot bebayune. Jenang sungsum disebut pula jenang abor-abor (Suwondo, 1982: 67). Jenang lain yang dijadikan unsur sesaji adalah jenang abang, putih dan baro-baro.

Jadah wajik dan lemper adalah makanan kecil yang biasa dijadikan suguhan di acara-acara hajatan. Selain sebagai suguhan makanan ini biasa digunakan sebagai ampilan acara pinangan atau di Jawa disebut lamaran. Makna simbolis makanan ini adalah gawe raket merekatkan tali persaudaraan. Makna simbolis perekat persaudaraan muncul dari hubungan makna kata dengan jenis benda yang dilambangkan. Jadah, wajik memiliki tekstur pliket, tekstur ini yang dijadikan dasar penentu referensi raket yang diambil dari silabe ket pada kata pliket. Raket adalah hubungan yang terjalin rapat, oleh karena itu wujud tekstur benda yang pliket menyebabkan jalinan unsur makanan terjalin kuat dan menyatu rapat. Kondisi ini yang dijadikan dasar penentu makna simbolis menjalin keakraban di antara keluarga yang akan berbesanan. Keakraban dua keluarga yang berbesanan diumpamakan dengan istilah yang lain pindha renggang kinepyur pulut, yang artinya dari yang berjarak menjadi rapat setelah ada perekatnya atau pulut. Itu sebabnya makanan yang terbuat dari beras ketan sering disebut sega pulut atau nasi pliket.

Berbeda dengan cara menentukan referensi pada jadah dan wajik, makanan jenis lemper meskipun sama-sama terbuat dari ketan, tetapi penentu referensi kata lemper dengan model etimologi primitif. Hubungan sign dengan referensi ditentukan oleh analisis kata lemper yang terdiri dari dua silabe lem dan per, yang menghasilkan referensi berdasarkan kondisi bendanya yang enak rasanya, yaitu dialem memper 
atau pantas untuk dipuji. Bermula dari referensi tersebut maka muncul makna simbolisme pujian terhadap keluarga besan yang membawa seserahan lemper yang nikmat rasanya.

\section{SIMPULAN}

Bahan utama yang paling banyak digunakan untuk membuat makanan tradisional adalah singkong (27\%), kemudian tepung beras (22\%), dan ketan (15\%). Singkong diolah menjadi makanan tradisional sebagai berikut: (1) madu sari, (2) gethuk, (3) mendut, (4) gathot, (5) thiwul, (6) bengawan solo, (7) sawut, (8) lenthuk, (9) geplak, (10) utri, dan (11) growol. Singkong juga dapat diolah menjadi pati singkong. Pati singkong kemudian diolah menjadi makanan tradisional seperti cethil dan cendhol. Tepung beras diolah menjadi: (1) nagasari, (2) lapis, (3) apem, (4) adrem, (5) srabi, (6) cara, (7) jenang sungsum, (8) jenang abang, dan (9) cucur. Sedangkan ketan akan diolah menjadi: (1) semar mendem, (2) hawuk-hawuk, (3) wajik, (4) jadah, (5) lemper.

Makanan tradisional di Kabupaten Bantul, berdasarkan cara pengolahannya dapat dikategorisasikan menjadi empat, yaitu: (1) dikukus, (2) digoreng, (3) dibakar, dan (4) direbus.

Berdasarkan hasil wawancara dengan pedagang dan produsen makanan tradisional di daerah Bantul, beberapa alternatif pengembangan yang dapat dilakukan adalah (a) identifikasi dan inventarisasi makanan tradisional, bekerjasama dengan Pusat Kajian Makanan Tradisional dan Perguruan Tinggi, (b) menyusun profil makanan tradisional di daerah sebagai bahan informasi pangan dan penyuluhan, (c) fasilitasi kepada asosiasi jasa boga, restoran, perhotelan, Perguiruan Tinggi dan masyarakat dalam penyebaran informasi, sosialisasi dan promosi, (d) pelatihan bagi tenaga penyuluh dan pendamping program mengenai informasi yang terkait dengan makanan tradisional (seperti menu dan pengembangan resep makanan, pengemasan, tata boga, mutu gizi, citarasa dan sanitasi), (e) mendorong pengembangan pusat-pusat makanan tradisional (Traditional Food Centre) bersama instansi terkait, swasta dan masyarakat, (f) pemberian kredit lunak untuk tambahan modal.

\section{DAFTAR PUSTAKA}

Kwik, J. 2008. Traditional Food Knowledge: A Case Study of an Immigrant Canadian "Foodscape" Environments. A Journal of InterDisciplinary Studies/Revue D'études Interdisciplinaires.

Kantor Pengelolaan Pasar Kabupaten Bantul. 2010. Lokasi Pasar yang Dikelola Kabupaten Tahun 2010. diunduh dari http: / / pasar.bantulkab.go.id / documents / 20100930092108 lokasi-pasar-yang-dikelola-kab pada 14 April 2013.

Kuhnlein, H.V. \& Receveur, O. 1996. Dietary Change and Traditional Food Systems of Indigenous Peoples. Annual Review of Nutrition, 16: 41744.

Retnaningsih, Ch., dan Pratiwi, A.R. 2004. Penampilan dan Penentuan Nilai Gizi Makanan Tradisional Berbasis Umbi di Kota Semarang. Program Studi Teknologi Pangan, Fakultas Teknologi Pertanian Unika Soegijapranata, Semarang.

Rosyidi, D. 2011. Macam-Macam Makanan Tradisional yang Terbuat dari Hasil Ternakyang Beredar di Kota Malang. 
Jurnal Ilmu dan Teknologi Hasil Ternak, Agustus 2006, Hal 24-34 Vol. 1, No. ISSN: 1978-0303.

Sukardi. 2011. Metodologi Penelitian Pendidikan. Yogyakarta: Bumi Aksara. Suwondo, Bambang. 1982. Upacara Tradisional DIY. Yogyakarta: Depdikbud http://www.suaramerdeka. com/v1/index.php/read / news / $2013 / 03 / 07 / 148082$ / Gerakan-Makanan-TradisionalHarus-Digalakkan.

http: //www.deptan.go.id/pesantren/ bkp/PKP/organisasi.htm. 